\title{
PENGGUNAAN MEDIA GAMBAR PUTAR PADA PROSES PEMBELAJARAN BAHASA DI TKM NU 134 HIDAYATUL UMMAH BALONGPANGGANG GRESIK
}

\author{
Riyadlotus Sholichah \\ riyadlotussholichah@staidagresik.ac.id \\ Sekolah Tinggi Agama Islam Daruttaqwa Gresik \\ Nur Kholifah \\ kholifah972@gmail.com \\ TKM NU 134 Hidayatul Ummah
}

\begin{abstract}
Aspects of language development is an important ability in the growth and development of children. Not all children aged 5-6 years are able to achieve very well developed indicators in language development. This encourages teachers to use learning media so that children's language skills can improve. The teacher applies the use of rotating image media in language learning. This research includes qualitative descriptive research. The purpose of this study was to determine the use of rotating image media in language learning in group B TKM NU 134 Hidayatul Ummah. The results showed that out of 47 children, children who met the achievement of indicators were at the BSB level (Developing Very Well), namely 18 and BSH (Developing According to Expectations) as many as 19 . However, there were 10 children who did not meet the achievement indicators, so how many at the MB level (Starting from Develop). From these data, it can be concluded that the use of rotating image media in the language learning process at TKM NU 134 Hidayatul Ummah is quite effective because most of the children are enthusiastic and meet the achievement indicators. Keywords: Playing Picture Media, Children's Language Learning
\end{abstract}

\begin{abstract}
Abstrak: Aspek perkembangan bahasa adalah kemampuan yang penting dalam tumbuh kembang anak. Tidak semua anak usia 5-6 tahun mampu mencapai indikator berkembang sangat baik pada perkembangan bahasa. Hal ini yang mendorong guru menggunakan media pembelajaran agar kemampuan bahasa anak dapat meningkat. Guru menerapkan penggunaan media gambar putar pada pembelajaran bahasa. Penelitian ini termasuk penelitian deskriptif kualitatif. Tujuan dari penelitian ini adalah untuk mengetahui penggunaan media gambar putar dalam pembelajaran bahasa di kelompok B TKM NU 134 Hidayatul Ummah. Hasil penelitian menunjukkan bahwa dari 47 anak, anak yang memenuhi pencapaian indikator berada pada tingkat BSB (Berkembang Sangat Baik) yaitu 18 dan BSH (Berkembang Sesuai Harapan) sejumlah 19. Namun terdapat 10 anak yang belum memenuhi pencapaian indikator sehingga berapa pada tingkat MB (Mulai Berkembang). Dari data tersebut, dapat disimpulkan bahwa penggunaan media gambar putar pada proses pembelajaran bahasa di TKM NU 134 Hidayatul Ummah cukup efektif karena sebagian besar anak antusias dan memenuhi pencapaian indikator.
\end{abstract}

Kata kunci : Media Gambar Putar, Pembelajaran Bahasa Anak.

\section{Pendahuluan}

Pendidikan Anak Usia Dini (PAUD) merupakan pendidikan untuk anak usia 0-8 tahun. Anak pada usia tersebut dipandang memiliki karakteristik yang berbeda dengan anak usia di atasnya sehingga pendidikannya perlu dikhususkan. PAUD bertujuan mengembangkan seluruh potensi anak agar kelak dapat berfungsi sebagai manusia yang utuh sesuai falsafah suatu bangsa. Menurut 
Jamaris perkembangan bahasa anak usia 5-6 tahun sudah dapat mengucapkan lebih dari 2.500 kosakata, lingkup kosakata yang dapat diucapkan anak menyangkut warna, ukuran, bentuk, rasa, bau, keindahan, kecepatan, suhu, perbedaan, perbandingan, jarak, dan permukaan (kasar-halus), anak usia 5-6 tahun sudah dapat berpartisipasi dalam suatu percakapan. Anak sudah dapat mendengarkan orang lain berbicara dan menanggapi pembicaraan tersebut. Percakapan yang dilakukan oleh anak 5-6 tahun telah menyangkut berbagai komentarnya terhadap apa yang dilakukan oleh dirinya sendiri dan orang lain, serta apa yang dilihatnya. ${ }^{1}$

Manusia dalam kehidupannya tidak terlepas dengan bahasa. Ia harus mampu menggunakan bahasa sebagai alat komunikasi. Dengan bahasa, mereka akan mudah dalam bergaul dan mudah menyesuaikan diri dengan lingkungannya. Bahasa mempunyai peranan yang sangat penting bagi kehidupan manusia. ${ }^{2}$ Dengan demikian perkembangan bahasa harus dirangsang sejak dini. Kemampuan berbahasa anak merupakan suatu hal yang penting karena dengan bahasa tersebut anak dapat berkomunikasi dengan teman atau orang-orang disekitarnya. Kemampuan berbahasa pada anak usia 4-6 tahun berdasarkan PERMENDIKNAS No. 58 tahun 2009 tanggal 17 September 2009 tentang standar tingkat pencapaian perkembangan bahasa anak meliputi: 1) menerima bahasa. Tingkat pencapaian perkembangan yang diharapkan adalah: menyimak perkataan orang lain, mengerti beberapa perintah secara bersamaan, memahami cerita yang dibacakan, mengenal perbendahaan kata mengenai kata sifat, mengulang kalimat yang lebih kompleks, memahami aturan dalan suatu permainan; 2) mengungkapkan bahasa. Tingkat pencapaian perkembangan meliputi: mengulang kalimat sederhana, menjawab pertanyaan secara sederhana, menyebutkan kata- kata yang dikenal, menceritakan kembali cerita atau dongeng yang pernah didengar, berkomunikasi secara lisan serta mengenal simbol-simbol untuk persiapan membaca, menulis dan berhitung; dan 3) keaksaraan. Tingkat pencapaian perkembangan yang diharapkan meliputi: mengenal suara-suara atau benda yang ada di sekitarnya, membuat coretan yang bermakna, meniru huruf, memahami hubungan bunyi dan bentuk huruf, membaca, dan menulis nama sendiri.

\section{Kajian teori}

Kemampuan Bahasa Anak dan Penggunaan Media

Metode bercerita merupakan salah satu pemberian pengalaman belajar bagi anak Taman Kanak-kanak melalui cerita yang disampaikan secara lisan. ${ }^{3}$ Bercerita adalah menuturkan sesuatu yang mengisahkan tentang perbuatan atau suatu kejadian dan disampaikan secara lisan dengan tujuan membagikan pengalaman dan pengetahuan kepada orang lain. Dengan demikian bercerita dalam konteks komunikasi dapat dikatakan sebagai upaya mempengaruhi orang lain melalui ucapan dan penuturan tentang sesuatu ide. Sementara dalam konteks pembelajaran anak usia dini bercerita dapat dikatakan sebagai upaya untuk mengembangkan potensi kemampuan berbahasa anak melalui

Ahmad, Susanto. Perkembangan Anak Usia Dini. (Jakarta: Kencana Prenada Media Group, 2011), hlm $78^{1}$

Suyatno.Permainan Pendukung Bahasa \& Sastra.(Jakarta: PT Grasindo, 2005), hal.12

${ }_{3}^{3}$ Moeslichatun.Media Pembelajaran di Taman Kanak - Kanak.(Jakarta: Rineka Cipta, 1996), hal. 194 
pendengaran dan kemudian menuturkannya kembali dengan tujuan melatih anak dalam bercakapcakap untuk menyampaikan ide dalam bentuk lisan. Kegiatan bercerita memberikan sumbangan besar pada perkembangan anak secara keseluruhan sebagai implikasi dari perkembangan bahasanya, sehingga anak akan memiliki kemampuan untuk mengembangkan aspek perkembangan yang lain dengan modal kemampuan berbahasa yang sudah baik.

Menurut Elizabeth B. Hurlock perkembangan bahasa anak usia dini ditempuh melalui cara yang sitematis dan berkembang bersama-sama dengan pertambahan usianya. Anak mengalami tahapan perkembangan yang sama namun yang menbedakan antara lain: sosial keluarga, kecerdasan, kesehatan, dorongan, hubungan, dengan teman yang turut mempengahurinya, ini berarti lingkungan turut mempengaruhi perkembangan bahasa anak, lingkugan yang baik maka perkembangan anak akan baik, namun sebaliknya jika tidak maka anak juga akan ikut dalam lingkungan tersebut. Hal ini lah yang menjadi tolak ukur atau dasar mengapa anak pada umur tertentu sudah dapat berbicara, atau pada umur tertentu belum bisa berbicara ${ }^{4}$.

Salah satu masalah yang terjadi pada sebagian besar anak di TKM NU 134 Hidayatul Ummah Balongpanggang Kabupaten Gresik adalah rendahnya kemampuan menceritakan kembali isi cerita karena guru masih menggunakan metode ceramah yang menimbulkan kebosanan anak pada saat kegiatan pembelajaran. Sebagian besar anak di TKM NU 134 Hidayatul Ummah Balongpanggang Kabupaten Gresik tidak bersemangat dan kurang tertarik dalam pembelajaran bahasa. Jumlah anak yang kurang antusias pada pembelajaran bahasa yaitu 15 anak.

Indikator pencapaian perkembangan anak usia 5-6 seharusnya sudah mampu menceritakan kembali isi cerita yang telah didengarnya. Pada indikator perkembangan linguistik anak usia 5-6 tahun diantaranya anak dapat Penerapan pengucapan dan tata bahasa; kosakata mencapai 900-1300 kata kompleks, susunan kalimat dan tata bahasa yang benar, menggunakan awalan; kata kerja sekarang, kemarin yang akan datang, rata-rata panjang kalimat meningkat menjadi 6-8 kata sosial, anak memiliki kontrol yang baik dari elemen percakapan. ${ }^{5}$

Selain itu, kegiatan menceritakan kembali isi cerita yang sangat jarang dilaksanakan pada anak sebelumnya menimbulkan faktor kemampuan bahasa anak pada saat kegiatan bercerita tidak dapat diserap anak dengan baik. Padahal kemampuan menceritakan kembali isi cerita merupakan keterampilan yang akan mendasari anak dalam memahami pembelajaran-pembelajaran di jenjang pendidikan selanjutnya. Banyak bentuk kegiatan pembelajaran kemampuan berbahasa yang dapat dilakukan dengan berbagai metode dan sudah tentu sesuai dengan prinsip belajar melalui bermain serta dalam suasana yang menyenangkan. Salah satu bentuk kegiatan tersebut yang termasuk dalam lingkup perkembangan bahasa sub mengungkapkan bahasa. ${ }^{6}$

Pembelajaran membaca melalui media gambar, secara individu anak diajak untuk permainan mencocokan gambar dengan kata dan guru bertindak sebagai fasilitator. Diharapkan dengan media gambar kemampuan membaca anak menjadi meningkat serta suasana pembelajaran menjadi

Elizabeth B. Hurlock. Perkembangan Anak. (Jakarta: Penerbit Erlangga, 1978), hal. $186^{4}$

5 5https://www.paud.id/2015/05/standar-tingkat-pencapaian-perkembangan-stpp-paud.html 02 Januari 202021.05 WIB

${ }^{6}$ Permendikbud No. 58 Tahun 2009 Tentang standar PAUD 
menarik dan menyenangkan. ${ }^{7}$ Anak mengalami hambatan dalam perkembangan untuk menceritakan kembali isi cerita. Anak juga terkadang berebut maju saat kegiatan pembelajaran jika guru menggunakan media-media baru yang sebelumnya tidak pernah diberikan kepada anak. Kemampuan guru dalam mengelola kegiatan yang masih monoton menggunakan metode ceramah membuat kegiatan pembelajaran terlihat semakin membosankan. Saat kegiatan bercerita nampak di kelas anak terlihat malas dan kurang tertarik mengikuti kegiatan. Ada anak yang berlari berkeliling kelas, ada yang bermain sendiri atau malah mengajak teman di sampingnya untuk berbicara. Peningkatan dan perubahan dalam pembelajaran meliputi metode dan media pembelajaran sangat penting untuk diperhatikan.

Pada dasarnya, taman kanak-kanak sebagai salah satu bentuk pendidikan anak usia dini yang berada pada jalur formal untuk anak usia 5-6 tahun, perlu mempersiapkan dan melakukan pembenahan diri dalam rangka menghadapi serta mamasuki era globalisasi, salah satu caranya dengan meningkatkan kemampuan bahasa pada anak melalui media cerita bergambar. ${ }^{8}$

Berdasarkan latar belakang masalah diatas, maka peneliti melakukan penelitian dengan judul Penggunaan Media Gambar Putar Pada Proses Pembelajaran Bahasa Di TKM NU 134 Hidayatul Ummah Balongpanggang Gresik. Penelitian ini hanya dibatasi pada pembahasan penggunaan media gambar putar pada perubahan penggunaan metode bercerita.

\section{Metode penelitian}

Penelitian ini termasuk penelitian kualitatif deskriptif, yaitu data yang dikumpulkan berbentuk kata-kata, gambar, bukan angka-angka. ${ }^{9}$ Menurut Bogdan dan Taylor, sebagaimana yang dikutip oleh Lexy J. Moleong, penelitian kualitatif adalah prosedur penelitian yang menghasilkan data deskriptif berupa kata-kata tertulis atau lisan dari orang-orang dan perilaku yang diamati. ${ }^{10}$ Sementara itu, penelitian deskriptif adalah suatu bentuk penelitian yang ditujukan untuk mendeskripsikan atau menggambarkan fenomena-fenomena yang ada, baik fenomena alamiah maupun rekayasamanusia. ${ }^{11}$ Penelitian ini digunakan untuk mengetahui bagaimana pelaksanaan penggunaan media gambar putar dalam pembelajaran bahasa di TKM NU 134 Hidayatul Ummah. Dalam hal pengumpulan data penelitian ini, peneliti terjun langsung pada objek penelitian untuk mendapatkan data yang valid, maka peneliti menggunakan metode sebagai berikut:

\footnotetext{
${ }^{7}$ Supriyanti. Peningkatan Kemampuan Berbahasa Melalui Media Gambar Anak Kelompok B I di TK TKK Tunas Kartini Moyudan Sleman Yogyakarta. https://journal.uny.ac.id > index.php > jpa > article 03 Januari 2020, 21.24 WIB

Sutami. Upaya Meningkatkan Kemampuan Berbahasa Melalui Media Cerita Bergambar Pada Anak Kelompok B di TK Wonorejo I Kecamatan Kedawung Kabupaten Sragen. eprints.ums.ac.id 03 Januari 2020, 21.24 WIB $^{8}$

9 9Sudarwan Danim, Menjadi Peneliti Kualitatif Rancangan Metodologi, Presentasi, dan Publikasi Hasil Penelitian untuk Mahasiswa dan Penelitian Pemula Bidang Ilmu Sosial, Pendidikan, dan Humaniora, (Bandung: Remaja Rosdakarya, 2002), hlm. 51.

${ }^{10}$ Lexy. J. Moleong, Metodologi Penelitian Kualitatif, (Bandung: PT Remaja Rosdakarya, 2000), hlm. 3

1111 Lexy. J. Moleong, Metodologi Penelitian Kualitatif, hlm. 17.
} 


\section{Metode Observasi}

Observasi ini menggunakan observasi partisipasi, yaitu peneliti terlibat langsung dengan kegiatan sehari-hari orang yang sedang diamati atau yang digunakan sebagai sumber data penelitian. ${ }^{12}$ Dalam observasi secara langsung, peneliti selain berlaku sebagai pengamat penuh yang dapat melakukan pengamatan terhadap gejala atau proses yang terjadi di dalam situasi yang sebenarnya yang langsung diamati oleh observer, juga sebagai pemeran serta atau partisipan yang ikut melaksanakan proses belajar bahasa dengan menggunakan media gambar putar di TKM NU 134 Hidayatul Ummah Balongpanggang Gresik, baik di dalam maupun di luar kelas.

\section{Metode Wawancara (Interview)}

Dalam melaksanakan penelitian ini, peneliti menggunakan wawancara terstruktur, di mana seorang pewawancara menetapkan sendiri masalah dan pertanyaan-pertanyaan yang akan diajukan untuk mencari jawaban atas hipotesis yang disusun dengan ketat. ${ }^{13}$ Metode wawancara peneliti gunakan untuk menggali data terkait pelaksanaan pembelajaran Bahasa dengan menggunakan media gambar putar di TKM NU 134 Hidayatul Ummah Balongpanggang Gresik. Informan dari wawancara yang dilakukan oleh peneliti adalah staf pengajar, kepala sekolah, dan pihak lain yang berkaitan dalam perolehan data penelitian ini.

\section{Metode Dokumentasi}

Melalui metode dokumentasi, peneliti gunakan untuk menggali data berupa dokumen terkait pembelajaran agama Islam, di antaranya: silabus, RPPH, dokumen penilaian, buku acuan pembelajaran, jadwal kegiatan pembelajaran, daftar nama siswa, sarana dan prasarana, foto-foto dokumenter, dan sebagainya.

\section{Hasil Dan Pembahasaan}

Setelah diperoleh beberapa data melalui observasi, wawancara, dn dokumentasi, maka peneliti akan menganalisa temuan berdasarkan data yang diperolah. Data tersebut tentang penggunaan media gambar putar pada pembelajaran bahasa di TKM NU 134 Hidayatul Ummah. Wawancara pada guru dilakukan untuk mengetahui efektivitas penggunaan media gambar putar dalam kegiatan pembelajaran bahasa khususnya menceritakan kembali isi cerita di TKM NU 134 Hidayatul Ummah.

Penggunaan Media Gambar Putar pada Proses Pembelajaran Bahasa di TKM NU 134 Hidayatul Ummah merupakan tindakan serta proses sadar dan bertanggung jawab yang dilakukan oleh guru untuk memberikan tindakan nyata kepada anak agar kemampuan bahasa anak dapat di asah sejak usia dini. Berikut ini beberapa temuan dan proses yang dilakukan guru dalam penggunaan media gambar putar pada proses pembelajaran bahasa di TKM NU 134 Hidayatul Ummah adalah sebagai berikut:

\footnotetext{
1212 Sugiyono, Metode Penelitian Pendidikan; Pendekatan Kuantitatif dan Kualitatif dan R\&D , (Bandung: Alfabeta, 2006), hlm. 310.

1313 Lexy. J. Moleong, Metodologi Penelitian Kualitatif, (Bandung: PT Remaja Rosdakarya, 2000), hlm.138.
} 
1. Perkembangan Bahasa Anak TKM NU 134 Hidayatul Ummah Sebelum Penggunaan Media Gambar Putar

Jumlah responden di kelompok B TKM NU 134 Hidayatul Ummah yaitu sebayak 47 anak. Berdasarkan hasil wawancara yang dilakukan peneliti dengan Bu Liswatin selaku guru kelas B TKM NU 134 Hidayatul Ummah, sebelum penggunaan media gambar putar pada pembelajaran bahasa,guru lebih banyak menggunakan buku cerita bergambar. Sebelumnya, Bu Liswatin langsung membacakan buku cerita di depan anak - anak kemudian mengulasnya. Pada pembelajaran ini anak hanya berperan sebagai pendengar cerita yang dibacakan oleh guru. Hal ini menimbulkan kondisi dimana anak cenderung bosan. Saat bosan, beberapa anakdi kelas B akan ramai dan berbicara dengan temannya. Hal ini menjadikan kondisi kelas tidak kondusif.

Selain itu, pembelajaran ini tidak melibatkan anak dalam bercerita sehingga kurang melatih kemampuan berbahasa anak. Meskipun dalam kelas B terdapat anak - anak yang sudah mampu berbahasa dengan baik, namun anak lain yang belum cukup berkembang dalam pembelajaran bahasa perlu adanya peningkatan. Hal ini menyebabkan Bu Liswatin mencoba penggunaan media baru yaitu media gambar putar. Penggunaan media gambar putar diharapkan mampu mengembangkan kemampuan anak dalam berbahasa.

\section{Pelaksanaan Pembelajaran Bahasa Menggunakan Media Gambar Putar}

Dari hasil observasi yang dilakukan peneliti, dapat diketahui bahwa penggunaan media gambar putar dalam kegiatan menceritakan kembali isi cerita di TKM NU 134 Hidayatul Ummah efektif. Berikut tahap pelaksanaan penggunaan media gambar putar pada pembelajaran bahasa di TKM NU 134 Hidayatul Ummah.

Berdasarkan hasil observasi dalam penggunaan media gambar putar, terlebih dahulu guru memperkenalkan media gambar putar pada anak. Guru memperlihatkan pada anak media gambar putar. Media ini memiliki bentuk seperti balok menyerupai televisi. Media ini memiliki dua alat putar yang masing - masing berada di atas tepi kiri dan kanan. Kemudian media ini berisi 6 gambar berbeda yang saling berhubungan dan memiliki alur cerita. Gambar dibuat semenarik mungkin untuk menarik perhatian anak dalam belajar bahasa. Pada bagian depan media ini, didesain sedemikian rupa agar gambar yang didalamnya dapat terlihat.

Setelah mengenalkan media gambar putar pada anak, guru menjelaskan pada anak cara menggunakan media ini dengan memutar alat putar ke kanan setiap mengganti gambar. Setelah anak menceritakan gambar pertama, maka anak harus memutar alat putar untuk beralih ke gambar berikutnya. Saat guru menjelaskan teknik penggunaan media, guru juga menjelaskan isi cerita pada anak agar ketika anak menggunakan media ini dapat juga menceritakan isi gambar dengan baik. Setelah itu, guru mempersilahkan anak untuk maju satu persatu dan menceritakan isi cerita pada media gambar putar. Saat anak bercerita di depan kelas, guru menilai proses penyampaian cerita. Dalam hal ini anak diharuskan menceritakan gambar dari awal sampai pada gambar terakhir.

Pada pembelajaran bahasa di TKM NU Hidayatul Ummah, anak maju satu per satu untuk menceritakan isi cerita pada gambar yang terdapat pada media gambar putar. Saat anak maju ke depan kelas menceritakan kembali isi cerita pada media gambar putar, anak dibimbing guru untuk 
memutar alat putar pada media agar gambar beralih ke urutan selanjutnya. Kemudian anak menceritakan isi cerita pada gambar dalam media mulai dari slide 1 hingga slide 6. Pada kegiatan pelaksanaan ini dapat dilihat tingkatan antusiasme anak dalam mengikuti pembelajaran bahasa menggunakan media gambar putar.

Pada proses pembelajaran terdapat 18 anak yang memiliki antusias tinggi dalam pembelajaran. 2 anak diantaranya terlihat antusias dengan sering bertanya saat kegiatan pembelajaran berlangsung, 9 anak fokus memperhatikan kegiatan pembelajaran dari awal hingga akhir, dan 7 anak diantaranya terlihat tidak sabar untuk segera maju ke depan kelas menceritakan gambar pada media gambar putar dan menggunakan media gambar putar tersebut. Pada dasarnya ke 18 anak yang antusias ini memiliki persamaan selalu mengikuti kegiatan pembelajaran dengan baik. Mereka juga selalu semangat saat guru menjelaskan dan menyuruh anak untuk maju bercerita. Selain itu, 19 anak berada pada tingkat antusias sedang. Mereka cenderung memperhatikan penjelasan guru di awal dan terlihat penasaran pada media gambar putar yang dibawa oleh guru saat pembelajaran bahasa. Namun 19 anak ini terkadang tidak memperhatikan penjelasan guru karena terpengaruh oleh anak lain yang ramai. Jumlah anak yang memiliki antusias rendah yaitu 10 anak. 7 anak yang memiliki antusias rendah terhadap pembelajaran bahasa menggunakan media gambar putar, cenderung lebih senang bermain. Dan 3 anak diantaranya kurang bisa terfokus pada kegiatan pembelajaran sehingga mudah teralihkan pada hal lain seperti bermain dan berbicara dengan teman.

Jadi penggunaan media gambar putar pada pembelajaran bahasa ini, sebagian besar mampu melatih anak dalam berbahasa khususnya menceritakan kembali isi cerita. Selain itu sebagian besar anak memiliki antusias tinggi dalam pembelajaran bahasa menggunakan media gambar putar. Hal ini dapat dikarenakan pengemasan media yang menarik, dapat diterima dan dipahami oleh anak.

\section{Perkembangan Bahasa Anak Kelompok B TKM NU 134 Hidayatul Ummah Setelah Penggunaan} Media Gambar Putar

Sesuai observasi dan wawancara yang dilakukan peneliti, pembelajaran bahasa yang telah dilakukan dengan menggunakan media gambar putar dapat dikatakan efektif. Hal ini terlihat pada saat kegiatan pembelajaran berlangsung, sebagian besar anak - anak terlihat semangat dan antusias dalam pembelajaran bahasa menggunakan media gambar putar. Menurut Bu Liswatin, hal ini dapat dikarenakan oleh tampilan media gambar putar yang cukup menarik yaitu seperti bentuk televisi dengan gambar dan warna yang cerah. Selain itu media ini belum pernah diterapkan di sekolah. Faktor lainnya yaitu penyampaian guru dalam menjelaskan penggunaan media serta ketika guru menceritakan isi cerita yang terdapat dalam media mampu dipahami oleh anak. Guru juga mampu menguasai kelas dan karakter anak.

Berdasarkan hasil penilaian kelas B dengan jumlah keseluruhan 47 anak, anak yang berada pada tingkat BSB (Berkembang Sangat Baik) sebanyak 18 anak, BSH (Berkembang Sesuai Harapan) sebanyak 19 anak, dan MB (Mulai Berkembang) sebanyak 10 anak. Anak - anak yang berada pada tingkat BSB adalah anak yang memiliki antusias tinggi dalam proses pembelajaran. Selain itu mereka memenuhi tiga indikator penilaian pada tabel diatas (menceritakan kembali isi cerita yang telah didengar, mengulang kalimat yang lebih kompleks, dan menyebutkan simbol - simbol huruf). 
Berikut penjelasan anak - anak yang berada pada tingkat BSB. Dalam hal ini peneliti hanya menjelaskan 3 anak sebagai perwakilan dari kelompok BSB :

1. Subyek 1. Inisial AMA. Ananda memiliki antusias tinggi dan mampu mengikuti kegiatan pembelajaran dari awal hingga akhir. Selain itu ananda juga mampu menceritakan kembali isi cerita secara beruntun. Ananda juga dapat mengulang kalimat yang lebih kompleks, serta mampu menyebutkan simbol huruf tanpa bantuan guru.

2. Subyek 2. Inisial AKZ Ananda mampu menceritakan isi cerita secara runtut dan jelas. Selain itu, dapat menceritakan isi gambar pada media gambar putar secara menyeluruh tanpa terpaku pada teks. Dalam kegiatan pembelajaran, ananda juga mampu mengulang kalimat yang lebih kompleks, serta dapat menyebutkan simbol huruf dengan benar.

3. Subyek 3. Inisial AHS. Ananda sangat antusias dalam pembelajaran bahasa menggunakan media gambar putar. Hal ini terlihat pada saat ananda tidak sabar saat mempraktekkan penggunaan media gambar putar di depan kelas. Ananda mampu menceritakan isi cerita dengan bahasanya sendiri. Selain itu mampu mengulang kalimat yang lebih kompleks, serta meyebutkan simbol huruf dengan benar.

Anak yang berada pada tingkat BSH (Berkembang Sesuai Harapan) pada pembelajaran bahasa menggunakan media gambar putar cukup antusias dalam kegiatan pembelajaran. Berikut penjelasan 3 perwakilan anak yang berada pada tingkat BSH (Berkembang Sesuai Harapan) :

1. Subyek 4. Inisial AHY. Ananda memiliki tingkat antusias cukup dalam pembelajaran bahasa menggunakan media gambar putar. Ananda cukup memperhatikan dalam kegiatan pembelajaran berlangsung. Sesekali ananda juga bertanya pada guru mengenai media gambar putar yang digunakan guru dalam pembelajaran bahasa. Ananda mampu menceritakan kembali isi cerita, meskipun terdapat kata yang terlewat. Selain itu mampu mengulang kalimat sederhana serta menyebutkan simbol - simbol huruf.

2. Subyek 5. Inisial LSZ. Ananda cukup antusias dalam kegiatan pembelajaran meskipun terkadang berbicara dengan temannya. Ananda mampu menceritakan kembali isi cerita, mengulang kalimat yang lebih kompleks, dan menyebutkan simbol - simbol huruf.

3. Subyek 6. Inisial AEP. Pada awalnya ananda terlihat antusias pada pembelajaran bahasa menggunakan media gambar putar. Namun di tengah pembelajaran ananda teralihkan pada kegiatan lain. Ananda mampu menceritakan kembali isi cerita, mengulang kalimat yang lebih kompleks, dan menyebutkan simbol - simbol huruf.

Anak pada tigkat MB (Mulai Berkembang), sebagian besar kurang antusias pada kegiatan pembelajaran bahasa. Berikut penjelasan 3 perwakilan anak yang berada pada tingkat MB :

1. Subyek 7. Inisial BCA. Pada awal pembelajaran, ananda sudah tidak terlihat antusias pada kegiatan pembelajaran bahasa menggunakan media gambar putar. Ananda cenderung tertarik pada permainan lain sehingga ananda masih perlu bimbingan dalam menceritakan kembali isi cerita pada media gambar putar. Dalam mengulang kalimat yang lebih kompleks, ananda masih perlu bimbingan dan mampu menyebutkan beberapa simbol huruf. 
2. Subyek 8. Inisial AA. Kemampuan ananda dalam menceritakan kembali isi cerita masih kesulitan dan perlu bimbingan guru. Hal ini dikarenakan ananda tidak memperhatikan guru saat menjelaskan kegiatan pembelajaran. Ananda belum mampu mengulang kalimat yang lebih kompleks dan hanya mampu mengulang beberapa kata. Selain itu, ananda hanya mampu menyebutkan beberapa simbol huruf.

3. Subyek 9. Inisial MHF. Sejak awal pembelajaran, ananda terlihat sering mengobrol dengan temannya. Hal ini berdampak pada kemampuan ananda saat menceritakan kembali isi cerita. Ananda masih perlu bantuan guru dalam hal bercerita. Selain itu ananda belum mampu mengulang kalimat yang lebih kompleks serta hanya mampu menyebutkan beberapa simbol huruf saja.

Dari hasil akhir tersebut dapat dikatakan bahwa media gambar putar memiliki kelebihan dan kekurangan dalam mendukung pembelajaran bahasa. Kekurangan media ini terdapat pada perlu adanya perbaikan dari segi gambar atau warna dan isi cerita agar seluruh anak dapat antusias dalam pembelajaran bahasa. Jadi berdasarkan hasil pengamatan peneliti, dapat disimpulkan bahwa penggunaan media gambar putar pada pembelajaran bahasa di TKM NU 134 Hidayatul Ummah mampu menarik minat anak dan cukup efektif dalam pembelajaran bahasa.

\section{Kesimpulan}

Setelah melalui proses penelitian dan penyajian hasil penelitian, maka penulis dapat mengungkapkan kesimpulan yaitu : Penggunaan media gambar putar pada pembelajaran bahasa di TKM NU 134 Hidayatul Ummah diterapkan melalui 3 proses atau langkah, yaitu :

a. Langkah persiapan dilakukan oleh guru dengan membuat RPPH (Rencana Pelaksanaan Pembelajaran Harian) agar pembelajaran memiliki tujuan jelas dan terarah sesuai kurikulum. Setelah itu guru mempersiapakan media pembelajaran yaitu media gambar putar pada pembelajaran bahasa. Media pembelajaran ini dibuat semenarik mungkin.

b. Langkah pelaksanaan yaitu guru menerapkan media gambar putar saat pembelajaran bahasa berlangsung sesuai pedoman RPPH yang telah dipersiapkan sebelumnya.

c. Langkah penilaian yaitu dilakukan guru pada saat pembelajaran berlangsung dengan memperhatikan kemampuan anak saat bercerita di depan kelas menggunakan media gambar putar.

Penggunaan media gambar putar pada pembelajaran bahasa di TKM NU Hidayatul Ummah memiliki dampak positif yang cukup besar dalam mengasah kemampuan berbahasa anak. Dampak positif tersebut meliputi meningkatnya kemampuan anak dalam menceritakan kembali isi cerita. Selain itu anak lebih antusias dalam pembelajaran bahasa. Sebelum penggunaan media gambar putar, dari 47 anak di Kelompok B terdapat 15 anak yang memiliki tingkat MB (Mulai Berkembang). Setelah penggunaan media gambar putar terdapat peningkatan dari 15 anak yang berada pada tingkat MB, menjadi 10 anak. Hal ini dapat disebabkan oleh desain media yang menarik serta kemampuan guru dalam menyampaikan materi di depan kelas. 


\section{Daftar Pustaka}

Ahmad, Susanto. 2011. Perkembangan Anak Usia Dini. Jakarta: Kencana Prenada Media Group

Elizabeth B. Hurlock. 1978. Perkembangan Anak. Jakarta: Penerbit Erlangga

Lexy. J. Moleong. 2000. Metodologi Penelitian Kualitatif. Bandung: PT Remaja Rosdakarya

Moeslichatun. 1996.Media Pembelajaran di Taman Kanak - Kanak. Jakarta: Rineka Cipta

Sudarwan Danim. 2002. Menjadi Peneliti Kualitatif Rancangan Metodologi, Presentasi, dan Publikasi Hasil Penelitian untuk Mahasiswa dan Penelitian Pemula Bidang Ilmu Sosial, Pendidikan, dan Humaniora, Bandung: Remaja Rosdakarya

Sugiyono. 2006. Metode Penelitian Pendidikan; Pendekatan Kuantitatif dan Kualitatif dan R\&D.

Bandung: Alfabeta

Supriyanti, 2020 Peningkatan Kemampuan Berbahasa Melalui Media Gambar Anak Kelompok B I di TK TKK Tunas Kartini Moyudan Sleman Yogyakarta. https://journal.uny.ac.id > index.php > jpa > article 03 Januari 2020, 21.24 WIB

Sutami. 2020, Upaya Meningkatkan Kemampuan Berbahasa Melalui Media Cerita Bergambar Pada Anak Kelompok B di TK Wonorejo I Kecamatan Kedawung Kabupaten Sragen. eprints.ums.ac.id 03 Januari 2020, 21.24 WIB

Suyatno. 2005. Permainan Pendukung Bahasa \& Sastra. Jakarta: PT Grasindo.

110 Sholichah, Kholifah - Penggunaan Media Gambar Putar 